Білак-Лук'янчук В.Й. ${ }^{1}$, Василенко В.В. ${ }^{2}$

\title{
Деякі показники захворюваності населення Закарпатської області
}

\author{
${ }^{1}$ ДВНЗ «Ужгородський національний університет», м. Ужгород, Україна \\ 2Закарпатський обласний центр громадського здоров’я, м. Ужгород, Україна \\ bilak.vika@gmail.com, viva60.net@gmail.com
}

Билак-Лукьянчук В.И. ${ }^{1}$, Василенко В.В. ${ }^{2}$

Некоторые показатели заболеваемости населения Закарпатской области

${ }^{1}$ ГВУЗ «Ужгородский национальный университет», г. Ужгород, Украина

2Закарпатский областной центр общественного здравоохранения, г. Ужгород, Украина
Bilak-Lukianchuk V.Y. ${ }^{1}$, Vasylenko V.V. ${ }^{2}$

Some indicators of the population morbidity in Transcarpathian region

${ }^{1} \mathrm{SU}$ "Uzhhorod National University”, Uzhhorod, Ukraine

${ }^{2}$ Transcarpathian Regional Public Health Center, Uzhhorod, Ukraine

\section{Ветуп}

Згідно з резолюцією Генеральної Асамблеї ООН 1979 року, здоров'я населення визначено єдиним критерієм доцільності та ефективності усіх без винятку сфер діяльності людини [1].

Одним з трьох основних напрямів розвитку України в соціальній сфері є створення ефективної системи охорони та відновлення фізичного здоров'я населення. Поряд із низьким рівнем соціального захисту окремих верств населення, наявністю безробіття та неконтрольованих міграцій серед основних загроз національній соціальній безпеці України названо низький рівень стану здоров'я населення та високий рівень його захворюваності [2].

Згідно вимог Методології Євростату (European Statistical System Committee - ESSC) [3], для оцінки стану здоров'я населення використовують чотири групи індикаторів, серед яких важливим індикатором $\epsilon$ захворюваність населення.

У даній статті наведено порівняльний аналіз за 5 років (2013-2017 рp.) захворюваності населення Закарпатської області та України в цілому за окремими класами хвороб.

Мета роботи - провести аналіз тенденцій динаміки показників захворюваності населення Закарпатської області у порівнянні 3 показниками захворюваності населення України.

\section{Матеріали та методи}

Матеріалами дослідження стали дані галузевої статистичної звітності в Закарпатській області за період 2013-2017 рр. При виконанні дослідження використано медико-статистичний метод та метод структурнологічного аналізу.

\section{Результати дослідження та їх обговорення}

На початку дослідження нами було вивчено показники загальної захворюваності населення Закарпатської області. Згідно зі статистичними даними [4], рівні вперше виявлених випадків загальної захворюваності по області були нижчими, ніж по Україні. Якщо по Україні відбувається деяка стабілізація показників, то в області намітилась тенденція до іiі зниження (рис. 1).

За роки дослідження загальний показник захворюваності населення Закарпатської області скоротився на 2,1\% і склав 58729,9 на 100 тис. населення.

Важливим для аналізу є показник захворюваності населення в працездатному віці. Згідно 3 даними державної статистики, у структурі захворювань населення працездатного віку перше місце посідають хвороби органів дихання (понад 33\%), друге - хвороби сечостатевої системи (понад 10\%), третє - травми, отруєння та інші дії зовнішніх причин (понад 8\%), четверте - хвороби органів крові та кровотворних органів (понад 7\%), п’яте - хвороби шкіри (понад 6\%).

Далі нами вивчалися та аналізувалися показники захворюваності населення за окремими класами хвороб.

Згідно з інформацією ВООЗ [2], 37\% всіх причин втрати працездатності припадає на інфекційну захворюваність. Тому ми вивчили та проаналізували показники захворюваності населення за класом «Деякі інфекційні та паразитарні хвороби».

За результатами аналізу, в Україні за останній проаналізований рік спостерігається тенденція до деякого підвищення рівня захворюваності населення за даним класом хвороб, а в області - його стабілізація (рис. 2).

За роки дослідження показники захворюваності населення Закарпатської області за класом «Деякі інфекційні та паразитарні хвороби» скоротилися на 9,3\% і склали 1529,4 на 100 тис. населення. 


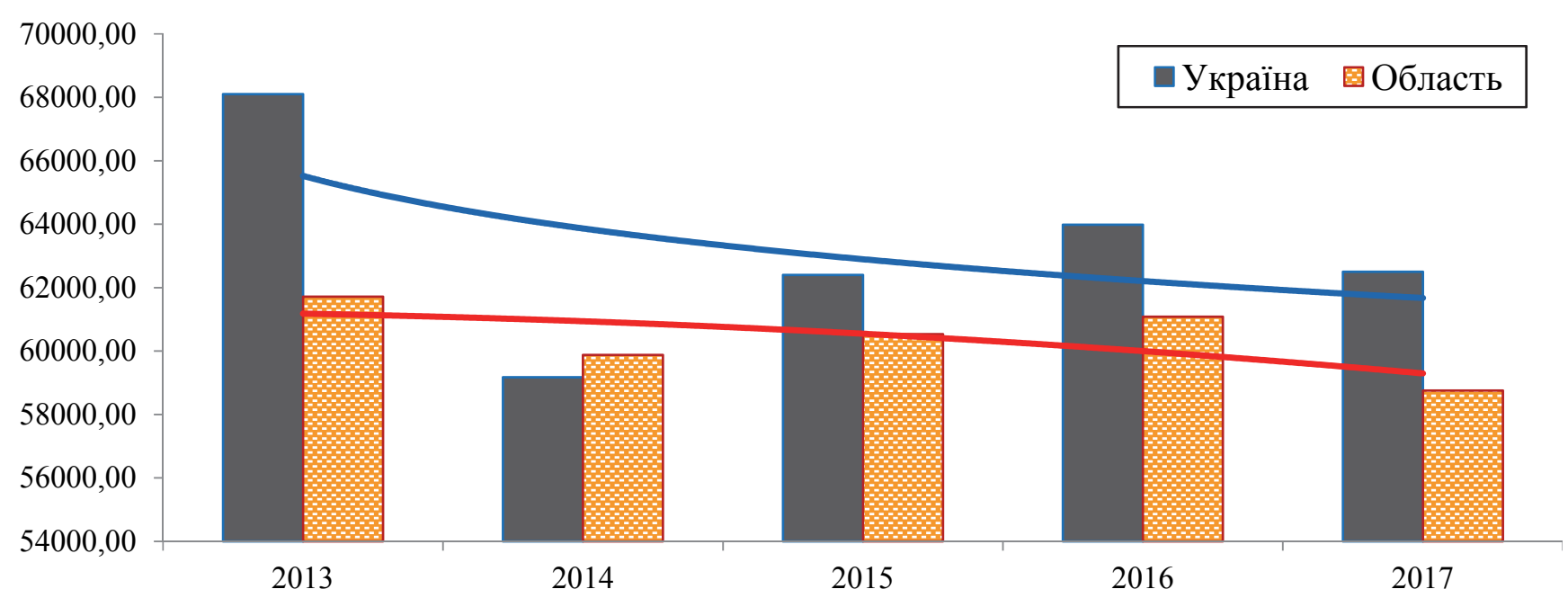

Рис. 1. Динаміка показників загальної захворюваності населення України та Закарпатської області, 2013-2017 рр. (на 100 тис. населення)

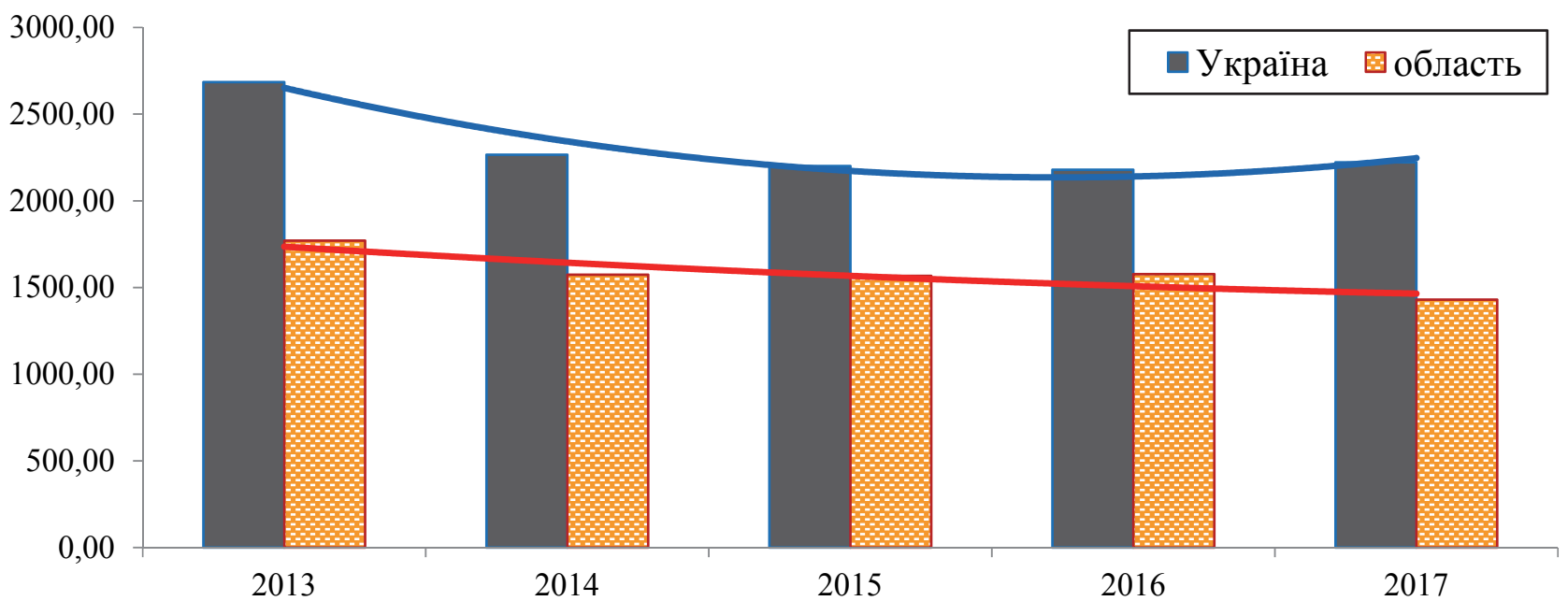

Рис. 2. Динаміка показників захворюваності населення України та Закарпатської області за класом «Деякі інфекційні та паразитарні хвороби», 2013-2017 рр. (на 100 тис. населення)

Далі вивчалися та аналізувалися показники захворюваності населення області на туберкульоз. При цьому необхідно зазначити, що в Україні епідемію туберкульозу ВООЗ офіційно оголосила у 1995 році. Високий рівень захворюваності населення України на туберкульоз та поширення його мультирезистентної форми обумовлені, насамперед, недостатнім та несвоєчасним виявленням хворих на різні форми туберкульозу та низькою ефективністю їх лікування.

За результатами аналізу [4], рівні захворюваності на туберкульоз перевищують показники по Україні, що вірогідно обумовлено приналежністю хворих до певних національних меншин Закарпаття (рис. 3).

За роки дослідження показники захворюваності населення Закарпатської області на туберкульоз зросли на $10,3 \%$ і склали 67,5 на 100 тис. населення.

Наступним кроком дослідження було вивчення та проведення аналізу показників захворюваності населення на хвороби системи кровообігу. За даними ВООЗ, 14\% серед всіх захворювань займають захворювання системи кровообігу [2]. В Україні вони також є однією з важливих медико-біологічних та соціальних проблем і займають приблизно 7-8\% всіх нозологій [5].

У Закарпатській області показники захворюваності населення на хвороби системи кровообігу з 2014 р. стали значно перевищувати загальнодержавні показники (рис. 4), що потребує додаткового вивчення регіональних причин їх виникнення. Можливо, одним із факторів $\epsilon$ високий рівень трудової міграції внаслідок несприятливих соціально-економічних умов в області.

Починаючи з 2014 року показники захворюваності населення Закарпатської області за класом «Хвороби системи кровообігу» зросли на 3,8\% і склали 4859,5 на 100 тис. населення.

Далі вивчалися та аналізувалися показники захворюваності населення на новоутворення.

Злоякісні пухлини у світі займають близько $8 \%$ від усіх захворювань [2]. За темпами поширення злоякісних 
новоутворень Україна посідає друге місце в Європі. В Україні щороку у понад 170 тис. осіб вперше діагностують онкологічну патологію, помирає до 90 тис. осіб, з них 35-37\% у працездатному віці [5].
Було встановлено, що показники захворюваності населення на новоутворення в Україні вищі, ніж в області, причому якщо в державі спостерігається їх зростання, то в області показники захворюваності стабільні і складають 668,7 на 100 тис. населення (рис. 5).

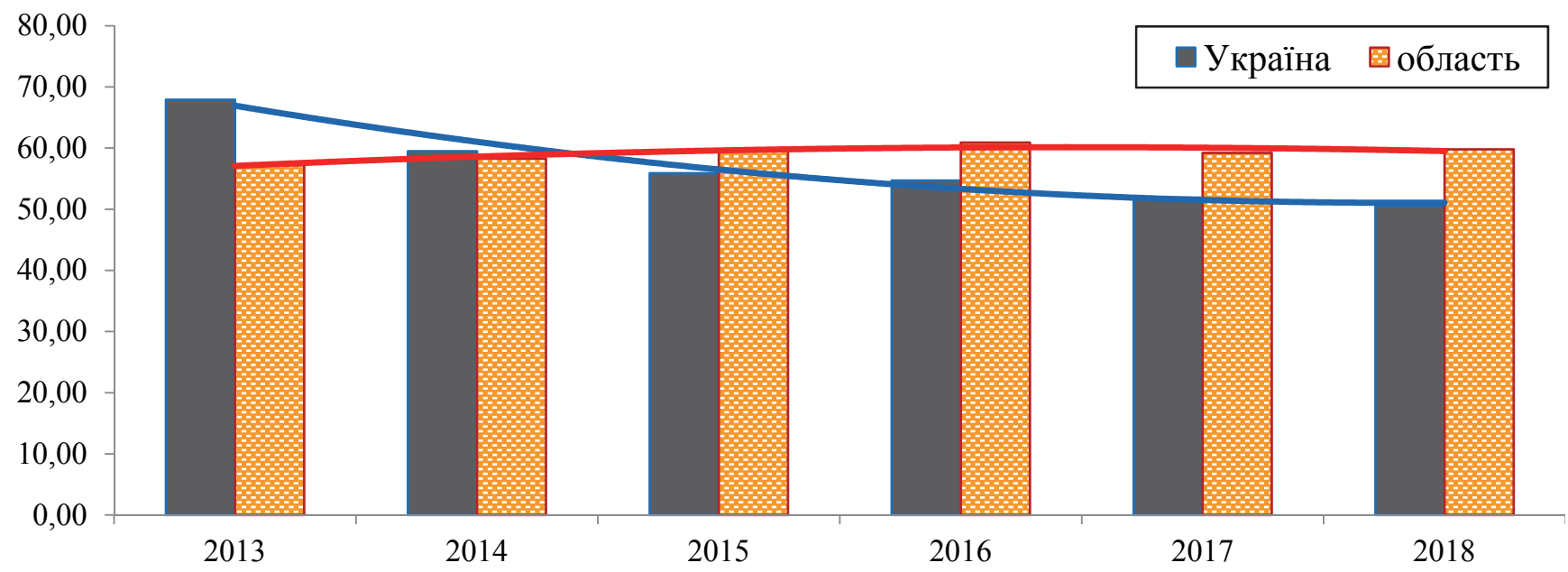

Рис. 3. Динаміка показників захворюваності населення на туберкульоз в Україні та Закарпатській області, 2013-2018 рр. (на 100 тис. населення)

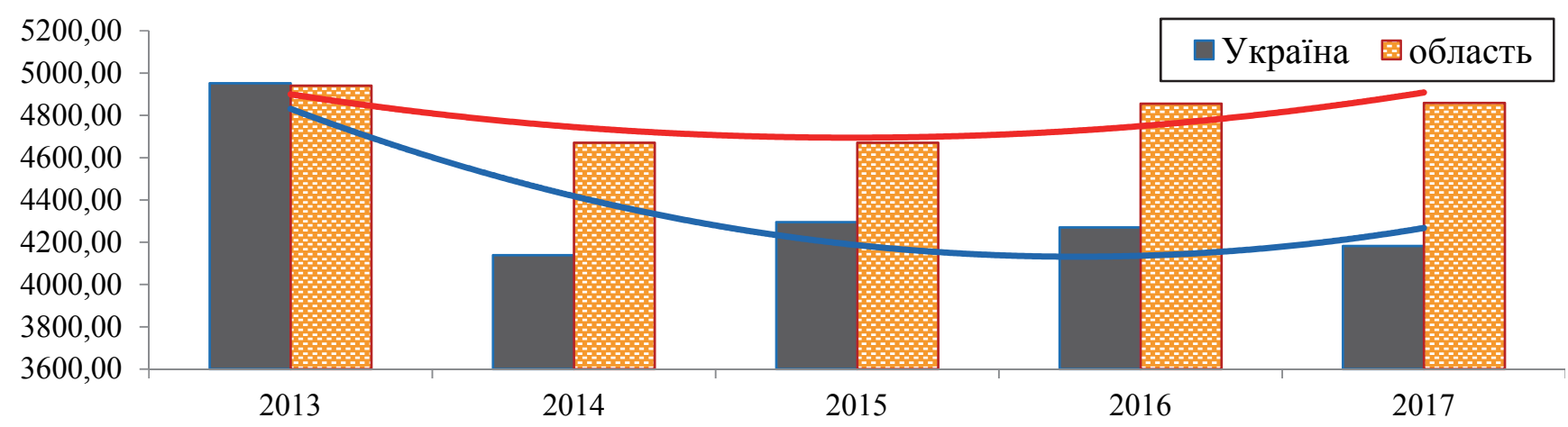

Рис. 4. Динаміка захворюваності системи кровообігу в Україні та області, 2013-2017 рр. (на 100 тис. населення)

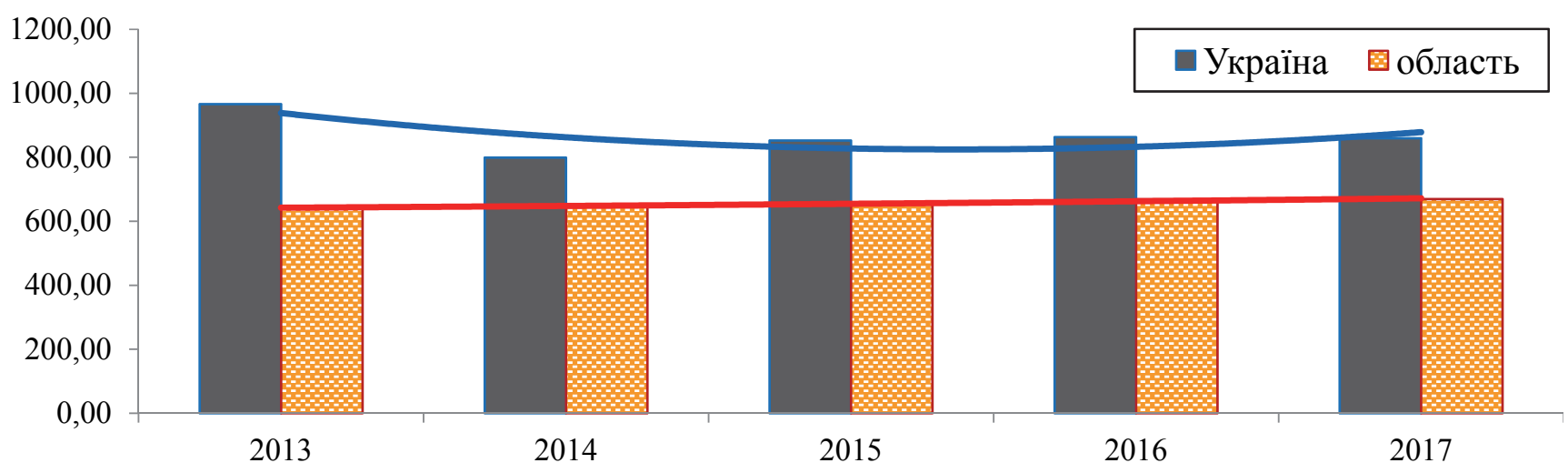

Рис. 5. Динаміка показників захворюваності на новоутворення в Україні та Закарпатській області, 2013-2017 pp. (на 100 тис. населення)

Перспективи подальших досліджень пов’язані 3 захворюваності населення Закарпатського регіону в вивченням та проведенням аналізу показників розрізі географічних зон та за окремими віковими 
категоріями. Завданням подальшого дослідження $\epsilon$ вивчення і оцінка впливу на здоров'я населення області соціальних, екологічних та міграційних процесів.

\section{Висновки}

В ході дослідження встановлено, що загальні показники захворюваності населення Закарпатської області за період 2013-2017 років мають тенденцію до зниження в склали 58729,9 на 100 тис. населення. При цьому показники за класом «Деякі інфекційні та паразитарні хвороби» скоротилися на 9,3\% і склали 1529,4 на 100 тис. населення, в тому числі показники захворюваності населення Закарпатської області на туберкульоз зросли на 10,3\% і склали 67,5 на 100 тис. населення. Починаючи 32014 року показники захворюваності населення Закарпатської області за класом «Хвороби системи кровообігу» зросли на 3,8\% і склали 4859,5 на 100 тис. населення, показники захворюваності на новоутворення в області стабільні і складають 668,7 на 100 тис. населення.

\section{Література}

1. Сайт ВОО3 [Електронний ресурс] - Режим доступу: http://www.who.int.

2. ВОО3 «Мировая статистика здравоохранения-2017» [Електронний ресурс] - Режим доступу: http://www.who.int/gho/publications/world_health_statistics/2017/ru.

3. Державна служба статистики України [Електронний ресурс] - Режим доступу: http://ukrstat.gov.ua.

4. Головне управління статистики у Закарпатській області [Електронний ресурс] - Режим доступу: http://www.uz.ukrstat.gov.ua/statinfo/statinfo.html.

5. База даних «Здоров'я для всіх. Україна»: Офіційний сайт Центру медичної статистики МОЗ України [Електронний ресурс] - Режим доступу: http://medstat.gov.ua/ukr/news.html?id=203.

\section{References}

1. Sayt VOOZ [Elektronnyi resurs] - Rezhym dostupu: http://www.who.int.

2. VOOZ «Myrovaia statystyka zdravookhranenyia-2017» [Elektronnyi resurs] - Rezhym dostupu: http://www.who.int/gho/publications/world_health_statistics/2017/ru.

3. Derzhavna sluzhba statystyky Ūkrainy [Elektronnyi resurs] - Rezhym dostupu: http://ukrstat.gov.ua.

4. Holovne upravlinnia statystyky u Zakarpatskii oblasti [Elektronnyi resurs] - Rezhym dostupu: http://www.uz.ukrstat.gov.ua/statinfo/statinfo.html.

5. Baza danykh «Zdorovia dlia vsikh. Ukraina»: Ofitsiinyi sait Tsentru medychnoi statystyky MOZ Ukrainy [Elektronnyi resurs] - Rezhym dostupu: http://medstat.gov.ua/ukr/news.html?id=203.

Дата надходження рукопису до редакції: 09.04.2019 p.

Мета роботи: провести аналіз тенденцій динаміки показників захворюваності населення Закарпатської області у порівнянні з показниками захворюваності населення України.

Матеріали та методи. Матеріалами дослідження дані галузевої статистичної звітності в Закарпатській області за період 2013-2017 pp. При виконанні дослідження використано медико-статистичний метод та метод структурнологічного аналізу.

Результати та обговорення. В ході дослідження встановлено, що загальні показники захворюваності населення Закарпатської області за період 2013-2017 років мають тенденцію до зниження в склали 58729,9 на 100 тис. населення, при цьому показники за класом «Деякі інфекційні та паразитарні хвороби» скоротилися на 9,3\% і склали 1529,4 на 100 тис. населення. В тому числі показники захворюваності населення Закарпатської області на туберкульоз зросли на $10,3 \%$ і склали 67,5 на 100 тис. населення. Починаючи з 2014 року показники захворюваності населення Закарпатської області за класом «Хвороби системи кровообігу» зросли на 3,8\% і склали 4859,5 на 100 тис. населення, показники захворюваності на новоутворення в області стабільні і складають 668,7 на 100 тис. населення.

Висновки. В цілому тенденції показників захворюваності населення Закарпатської області відповідають загальнонаціональним тенденціям крім класу «Хвороби системи кровообігу»: тоді як в області відмічаються тенденції до зростання показника, в країні в цілому він знижується.

Ключові слова: Закарпатська область, населення, захворюваність, інфекційні хвороби, хвороби системи кровообігу, новоутворення.

Цель работы: провести анализ тенденций динамики показателей заболеваемости населения Закарпатской области по сравнению с показателями заболеваемости населения Украины. 
Материалы и методы. Материалами исследования стали данные отраслевой статистической отчетности в Закарпатской области за период 2013-2017 гг. При выполнении исследования использованы медико-статистический метод и метод структурно-логического анализа.

Результаты и обсуждение. В ходе исследования установлено, что общие показатели заболеваемости населения Закарпатской области за период 2013-2017 годов имеют тенденцию к снижению в составляют 58729,9 на 100 тыс. населения, при этом показатели по классу «Некоторые инфекционные и паразитарные заболевания» сократились на 9,3\% и составили 1529,4 на 100 тыс. населения. В том числе показатели заболеваемости населения Закарпатской области туберкулезом выросли на 10,3\% и составили 67,5 на 100 тыс. населения. Начиная с 2014 года показатели заболеваемости населения Закарпатской области по классу «Болезни системы кровообращения» выросли на 3,8\% и составили 4859,5 на 100 тыс. населения, показатели заболеваемости новообразованиями в области стабильны и составляют 668,7 на 100 тыс. населения.

Выводы. В целом тенденции показателей заболеваемости населения Закарпатской области соответствуют общенациональным тенденциям кроме класса «Болезни системы кровообращения»: тогда как в области отмечаются тенденции к росту показателя, в стране в целом он снижается.

Ключевые слова: Закарпатская область, население, заболеваемость, инфекционные заболевания, болезни системы кровообращения, новообразования.

The aim of the article is to analyze the trends in the dynamics of population morbidity of Transcarpathian region in comparison with the morbidity of the population of Ukraine.

Materials and methods. The research materials include sectoral statistical reporting in Transcarpathian region during 2013-2017. The medical-statistical method and the method of structural-logical analysis were used in this study.

Results and discussion. The study found that the overall morbidity of the population of Transcarpathian region for $2013-$ 2017 tends to decrease to 58729.9 per 100,000 population, while the indicators of the category "Some infectious and parasitic diseases" decreased by $9.3 \%$ and amounted to 1529.4 per 100,000 population. Including the incidence of tuberculosis in Transcarpathian region increased by $10.3 \%$ and amounted to 67.5 per 100,000 population. Since 2014 indicators of population morbidity in Transcarpathian region in the category "Diseases of circulatory system" increased by $3.8 \%$ and amounted to 4859.5 per 100,000 population, the incidence of tumors in the region is stable and is 668.7 per 100,000 population.

Conclusions. In general, the trends of morbidity of the population of Transcarpathian region correspond to national trends, except for the category "Diseases of circulatory system": as in the region it is growing, in the country as a whole, it is declining.

Key words: Transcarpathian region, population, morbidity, infectious diseases, diseases of the circulatory system, tumors.

Конфлікт інтересів: відсутній.

Conflicts of interest: authors have no conflicts of interest to declare.

\section{Відомості про авторів}

Білак-Лук'ячук Вікторія Йосипівна - к.мед.н., доцент кафедри наук про здоров’я Ужгородського національного університету; 88000 пл. Народна, 3, м. Ужгород, Україна.

+380 (50) 597-05-99, bilak.vika@gmail.com.

Василенко Вікторія Василівна - к.мед.н., лікар-епідеміолог, Закарпатський обласний центр громадського здоров'я; 88000, вул. Другетів, 72, м. Ужгород, Україна.

+380(50) 808-64-20, viva60.net@gmail.com. 